\title{
Terapeuttista lukemistyötä Ruotsin malliin
}

\section{Cecilia Pettersson: Biblioterapi. Hälsofrämjande läsning i teori och praktik. Stockholm: Appell Förlag, 2020, $231 \mathrm{~S}$.}

Göteborgin yliopiston kirjallisuudenlehtori Cecilia Pettersson osallistuu tuoreella tietokirjallaan ajankohtaiseen lukemisen terveyshyötyjä käsittelevään keskusteluun. Fokus on ruotsalaisessa kirjallisuusterapiassa, biblioterapi, joka määritellään terveyttä edistäväksi lukemistoiminnaksi. Käsitehistoriallisen alkukatsauksen jälkeen Pettersson esittelee kirjallisuusterapeuttisen toiminnan teoreettisia lähtökohtia ja kansainvälisiä suuntauksia. Pääpaino on nykyisessä hyvinvointia edistävässä lukemistyössä sekä lukemistutkimushankkeissa, joissa tekijä on ollut mukana.

Ruotsissa lukemisen edistäminen koetaan yhtä lailla tärkeäksi kuin meillä. Naapurimaassa lukemistyö mielletään kuitenkin kirjallisuusterapeuttiseksi, ja medioissa monenlaista lukupiiritoimintaa esitellään kirjallisuusterapiana. Käytännössä se voi tarkoittaa kirjavinkkausta, kuten suositussa Babel-kirjallisuusohjelmassa, jossa tunnetut kirjailijat ja julkisuuden henkilöt suosittelevat oman lukukokemuksensa pohjalta tiettyä kirjaa erinäisiin ongelmiin. Yhtä hyvin se voi tarkoittaa kirjastoissa ja työnväenopistoissa järjestettyä lukupiiritoimintaa, jossa keskitytään tiettyyn teemaan tai ongelmaan, kuten masennukseen, avioeroon tai lapsen itsemurhaan. Esimerkiksi Läsa för livet on kansanvalistuspohjainen hanke, josta kirjallisuusterapeuttisen lukupiirin ohjaaja voi hakea ja saada organisointi- ja ohjaustukea.

Niin tärkeää kuin tällainen lukemisen edistämistyö ilman muuta onkin, jää medioiden esittämä kuva kirjallisuusterapiasta hyvin yksiulotteiseksi. Kirjallisuusterapia tarkoittaa meillä ja maailmalla paljon muutakin kuin "kirjoja reseptillä" (böcker på resept). Tarvetta alan perusteellisemmalle ja monipuolisemmalle esittelylle siis on.

Kirjallisuusterapiaa kirjallisuudentutkijan vinkkelistä

Biblioterapi-kirjassa ilmenee tekijän kirjallisuustieteellinen tausta - hyvässä ja pahassa. Oppialansa kautta Pettersson tuntee kirjallisuuden lajikartan ja lukemisteoriat. Hän on muistin representaatioita käsittelevän väitöskirjansa jälkeen kiinnostunut lukemisen psykologiasta ja alkanut perehtyä kirjallisuusterapian teoriaan. Nyt hän haluaa vahvistaa alan tuntemusta Ruotsissa ja valaa 
tukevampaa maaperää myös kirjallisuusterapeuttiselle tulevaisuuden työlle: käytännön toiminnalle, teorialle ja tutkimukselle, omalle tutkimukselleenkin.

Petterssonia kiinnostavat kirjallisuuden lukemiseen liittyvät hyötyväitteet ja erityisesti keskustelut tiettyjen kirjallisuuden lajien vaikuttavuudesta. Pettersson argumentoi kiivaasti korkeakirjallisen kaunokirjallisuuden lukemista suosittelevaa brittiläistä Shared reading -lukupiirimenetelmää vastaan, joka on saanut jalansijaa Ruotsissakin. Petterssonin omat lukemisen kokemuksellisuuteen keskittyvät tutkimukset $(2016,2018)$ ovat antaneet aihetta ajatella, että viihdekirjallisuus voi tietyssä elämäntilanteessa, esimerkiksi sairauslomalla tai masennuksen vaiheissa, palvella osallistujien hyvinvointia korkeakirjallisuutta paremmin. Pettersson löytää väitteilleen tukea angloamerikkalaisen kirjallisuusterapian (bibliotherapy) lukemisterapeuttisesta suuntauksesta. Erityisesti hän tukeutuu brittiläiseen kirjastotieteen tutkijaan Liz Brewsteriin, joka on väitöskirjassaan tutkinut brittiläistä kirjallisuusterapiaa ja puolustanut viihdekirjallisuuden lukemista.

Pettersson keskittyy kirjassaan lukemisterapeuttiseen toimintaan, mutta kuva luovasta kirjallisuusterapiasta jää edelleen kapeaksi ja teoreettiseksi, kun tekijällä ei itsellään ole alan koulutusta eikä työkokemusta. Luovaa vuorovaikutteista kirjallisuusterapiatyötä voidaan kuitenkin kirjastojen ja työväenopistojen lisäksi toteuttaa myös opetustyössä, sosiaali- ja terveydenhoidossa sekä itsenäisenä tai psykoterapiaan tai muuhun luovaan terapiaan integroituna terapiamenetelmänä. Kirjallisuustieteellä on toki annettavaa kirjallisuusterapialle, mutta lisäksi tarvitaan muuta: psykologiaa, psyko- tai taideterapeuttista osaamista, vuorovaikutus- ja tunnetaitoja - toisin sanoen tietoa siitä, miten kirjallisuuden vaikutusten ja ihmisten lukukokemusten kanssa käytännössä toimitaan. Työtä ei oikeastaan tehdäkään sanojen kanssa, vaan työ tapahtuu ihmisten välillä. Kirjallisuusterapiassa kirjallisuus on vuorovaikutuksen ja tunteensiirron väline, eikä sen vaikutuksia ja käyttöä voi opetella yksinomaan kirjoista, teorian pohjalta.

\section{Esimerkkiä ja potkua Ruotsista}

Teoriaa toki tarvitaan, ja Pettersson onnistuukin tutkijataustansa vuoksi tekemään hyviä kysymyksiä ja valaisevia oivalluksia. Hänen omien tutkimusmatkojensa aikana syntynyt käsitys lukemisen hoitavuudesta tarjoaa myös hyvää pohjaa tulevaisuuden tutkimuksille: terapeuttinen lukeminen ei ole mikään yksiselitteinen malli tai yksioikoinen menetelmä, vaan joukko erilaisia lähestymistapoja. Mitään suoraa avainta onneen ja hyvinvointiin ei viihdekirjallisuuden lukeminenkaan Petterssoninkaan mukaan tarjoa, vaan hyvinvointiin vaikuttavat monet asiat.

Petterssonin kirjassaan tekemät johtopäätökset ja tulevaisuuden visiot tuovat monin paikoin mieleen Suomessa harjoitettavan luovan ja vuorovaikut- 
teisen kirjallisuusterapian. Täysin tuntematon suomalainen kirjallisuusterapia ei kirjoittajalle tietenkään ole, sillä hän on toiminut kouluttajana Tukholmassa Ersta Sköndal Bräcke -korkeakoulussa kirjallisuusterapian peruskurssilla, jonka johtajalla, Pia Bergströmillä, on Suomen mallin mukainen kirjallisuusterapiaohjaajakoulutus. Pettersson viittaa Suomeen kuitenkin vain ohimennen ehkäpä siitä syystä, että alan kirjallisuus on kirjoitettu enimmäkseen suomeksi. Poikkeuksia toki alkaa olla, sillä viime vuosina on julkaistu englanniksi kirjoitettuja kirjoja ja artikkeleita, mutta näihin Petterssonilla ei ole ollut vielä aikaa perehtyä.

Tervehdin kuitenkin ilolla Petterssonin teosta ja ylipäätään ruotsalaiseen kulttuuriin kuuluvaa reipasta aloitteellisuutta. Sen tuloksena naapurimaassa on lähdetty vauhdilla luomaan toimintaedellytyksiä kirjallisuusterapeuttiselle toiminnalle ja lukuisille erilaisille tutkimus- ja seurantahankkeille. Ja kun kirjoittajan silmissä siintää kohtalaisen kirkkaana ruotsalaisen kirjallisuusterapian tulevaisuus, jään toiveikkain mielin seuraamaan alan kehittymistä Ruotsissa. Ehkä saamme siitä toivottua lisäpotkua myös Suomeen, jossa on Euroopan vanhin, 1981 perustettu, kirjallisuusterapiayhdistys, ja jossa alan opetusta on annettu 1990-luvulta lähtien.

Päivi Kosonen 